\title{
Effect of sucrose in a holding solution on some processes associated with ageing of cut carnations
}

\author{
ALEKSANDRA LUKASZEWSKA
}

Department of Ornamental Plants, Institute of Horticulture Production, Warsaw Agricultural University, Nowoursynowska 166, 02-766 Warszawa

(Received: October 11, 1979)

Abstract

Vase-life of cut carnations and their response to a preservative (8-HQS $+\mathrm{S})$ depended on the sucrose and reducing sugar content in the petals at the time of harvest. The reducing sugar level decreased in the wilted flowers kept in water and increased above the initial level in the carnations given sucrose in a holding solution. This increase in reducing sugars was small or 2-3 fold in the flowers with high and low initial sugar levels, respectively. Changes in the endogenous sucrose levels in the petals were less pronounced but a trend (i.e. increase-decrease) was also dependent on the initial sucrose level. Considerable sucrose accumulation was found in the leaves of plants placed in the solution of 5\% sucrose plus $200 \mathrm{ppm}$ 8-HQS. Use of an exogenous sugar in a holding solution prevented an increase in free amino acids in carnation petals, a symptom for flower ageing. Carnations placed in a preservative solution had a her anthocyanin content then the control flowers. Lower activities of acid phosphatases and RNases were found in the flowers placed in the solutions tested as compared to those kept in water.

\section{INTRODUCTION}

Longevity of cut flowers is usually shorter as compared to that of intact flowers left on plants. One of the causes of this phenomenon is a depletion of the limited supply of assimilates resulting in incomplete flower development and a decrease in their life span. Supplying the cut flowers with sugar together with an antiseptic enables them to develop normally (F a r n a m et al., 1971), prolongs their vase-life (A a r ts, 1957) and prevents color changes (W e instein, 1957).

During investigations on the effects of various holding solutions on cut carnations an improvement in their keeping qualities was generally 
observed but the response of flowers to the chemicals varied, for example the increase in vase-life due to the solution of 8-hydroxyquinoline sulphate plus sucrose observed by $€ u k$ as ze w s a (1978) in the course of three year experiments ranged from $18 \%$ to $103 \%$. The works of $\mathrm{Bunt}$ (1978) and $\mathrm{P}$ a ul et al. (1977) have shown that considerable seasonal variations occurred in the quality of carnation flowers due to such environmental factors as light and temperature. Since their abservations suggest that cut cernation longevity is associated with carbohydrate status of plants, the levels of reducing sugars and sucrose in the petals were determined in this work and compared in relation to the subsequent vase-life. In order to check the effect of the chemicals on some degradative processes occurring during flower ageing, i.e. depletion of respiratory substrate, decrease in proteins, color chonges and an increase in the hydrolytic enzymes, the levels of reducing sugars, sucrose, free amino acids, anthocyanins and the activities of acid phosphatases and RNases were determined in the petals of cut carnations placed in water or in preservative solutions.

\section{MATERIAL AND METHODS}

Flowers for these experiments were acquired from several sources: State Horticultural Farm Mysiadło (2 XII 1975, 15 III 1976), SHF Owii-ska (1 VII 1976) and the private enterprise of A. Gąsowski (19 IV 1977). The flowers were cut when the outer whorl of petals had just unfolded. The experiments were carried out in a room with temo. $13-22^{\circ} \mathrm{C}$ $50-70 \%$ relative humidity and light intensity about 1000 lux. Simultaneously with the observations on flower keeping qualities biochemical analyses were performed on parallel batches of flowers. For these analyses 2-3 petals of the outer whorl were collected from 10 flowers of each treatment. Leaf samples were taken from the second upper pair. Plant material was finely cut and mixed and the samples were then weighed. Three extracts were prepared from each treatment and three aliquots were taken from each of these for determinations. Reducing sugars and sucrose were determined in an $80 \%$ ethanol extract according to $\mathrm{Nelson}$ (1944), sucrose being estimated as a difference in reducing sugars before and after hydrolysis with $0,2 \mathrm{~N} \mathrm{HCl}$. Both sugars were expressed as $\mathrm{mg}$ glucose per gram of fresh or dry matter. Free amino acids were determined in the same alcohol extract by the ninhydrin method of Rosen (1957) and expressed as micromoles of leucine per gram fresh weight. Material for enzymatic determinations was homogenized in $0,05 \mathrm{M}$ Tris- $\mathrm{HCl}$ buffer pH 8,5 with 5 miM mercaptoethanol. Extracts were centrifuged at $0^{\circ} \mathrm{C}$ at $12000 \mathrm{rpm}$ for $10 \mathrm{~min}$. Supernatants were immediately used for protein and enzyme determi- 
nations. Protein content was determined according to Low ry et al. (1951). RNases were estimated by the method of $\mathrm{Tuve}$ and Anfins e n (1960) and expressed in activity units per $\mathrm{mg}$ of protein. The activity unit was the amount of enzyme required to increase the absorbance of the reaction mixture of 1 O.D. unit in 1 hour. Acid phosphatases were determined according to Torib and Warner (Ty s a r o w sk i, 1968) using sodium $\beta$-glycerophosphate as a substrate. Amounts of inorganic phosphorous released in the extracts were estimated according to the calibration curve prepared for $\mathrm{K}_{2} \mathrm{HPO}_{4}$ and calculated per mg of protein. Anthocyanins were determined after extracting the air-dried retals with $1 \% \mathrm{HCl}$ in methanol and expressed as $\mathrm{E} \times 10^{3}$ at $520 \mathrm{~nm}$. The results of analyses were subjected to the analysis of variance and the Student t-test was used to evaluate the differences between the means at the probability level $\mathrm{P}=0,99$.

\section{RESULTS}

The results of sugar determinations in cut carnation petals are shown in Table 1 . The content of reducing sugars in the freshly cut flowers ranged from 7,5 to $22,4 \mathrm{mg}$ per gram fresh weight. A considerable decrease in reducing sugars at wilting - as compared to their level in the fresh flowers - was observed in the petals of flowers kept in water. In carnations placed in the preservative solution an accumulation of reducing sugars occurred, the increase being negligible in the case of flowers initially rich in carbohydrates and $2-3$ fold in carnations with low initial sugar levels. Including benzyladenine in the solution of sucrose plus 8-HQS suppressed the accumulation of reducing sugars and also considerably less were found in flowers placed in the solution of glucose with 8-HQS and CCC.

Smaller changes than in reducing sugars were found in sucrose levels in the petals at the time of wilting as compared to the fresh flowers (Table 1). In material with a high sugar level a decrease in sucrose was observed in all treatments and its content in the wilted petals averaged half of the initial level. In carnations which had much less sucrose at the moment of harvest its content remained at the initial level or increased in the flowers held in water or a preservative solution, respectively.

The results of analyses of sugar content in cut carnation leaves are shown in Table 2. No reducing sugars were found in the leaves at the beginning of the experiments. After 7-11 days, i.e. at the time of wilting, reducing sugars appeared in small quantities, their levels in the sucrose fed plants being three times higher than in the control treatment. In the leaves of carnations placed in the preservative sol- 


\section{Table 1}

Fffect of holding solutions on the level of sucrose, reducing sugars (mg glucose/g fresh weight) and free amino acids (micromoles leucine/g fresh weight) in the petals of cut carnations determined in fresh and wilted flowers

\begin{tabular}{|c|c|c|c|c|c|c|c|}
\hline \multirow[b]{2}{*}{$\begin{array}{c}\text { Dates of } \\
\text { experiments }\end{array}$} & \multirow[b]{2}{*}{$\begin{array}{l}\text { Kind of } \\
\text { analysis }\end{array}$} & \multirow{2}{*}{$\begin{array}{l}\text { At the } \\
\text { time of } \\
\text { harvest }\end{array}$} & \multicolumn{5}{|c|}{ At the time of wilting } \\
\hline & & & $\begin{array}{l}\text { water } \\
\text { control }\end{array}$ & $\begin{array}{c}\text { 8-HQS } \\
+\mathrm{S}\end{array}$ & $\begin{array}{c}8-\mathrm{HQS}+\mathrm{S} \\
+\mathrm{BA}\end{array}$ & $\begin{array}{c}\text { 8- } \mathrm{HQS}+\mathrm{G} \\
+\mathrm{CCC}\end{array}$ & $\begin{array}{l}\text { LSD at } \\
\mathrm{P}=0.99\end{array}$ \\
\hline \multirow[t]{2}{*}{ 2. XII 1975} & $\begin{array}{l}\text { sucrose } \\
\text { reducing }\end{array}$ & 13.0 & 4.9 & 12.1 & - & - & 3.8 \\
\hline & sugars & 11.0 & 4.6 & 35.1 & - & - & 2.6 \\
\hline \multirow[t]{3}{*}{15 III 1976} & $\begin{array}{l}\text { sucrose } \\
\text { reducing }\end{array}$ & 7.0 & 7.3 & 11.8 & - & - & 2.4 \\
\hline & sugars & 7.5 & 2.9 & 24.7 & - & - & 3.8 \\
\hline & $\begin{array}{l}\text { free } \\
\text { aminoacids }\end{array}$ & 16.4 & 34.2 & 14.4 & - & - & 3.1 \\
\hline \multirow[t]{3}{*}{1 VII 1976} & $\begin{array}{l}\text { sucrose } \\
\text { reducing }\end{array}$ & 7.2 & 6.5 & 6.1 & 5.1 & 5.2 & 1.6 \\
\hline & $\begin{array}{l}\text { sugars } \\
\text { free }\end{array}$ & 10.1 & 7.1 & 26.1 & 21.0 & 11.1 & 1.8 \\
\hline & aminoacids & 24.1 & 43.6 & 26.8 & 18.8 & 26.6 & 9.2 \\
\hline \multirow[t]{3}{*}{19 IV 1977} & $\begin{array}{l}\text { sucrose } \\
\text { reducing }\end{array}$ & 20.0 & 7.1 & 11.9 & 13.9 & 11.4 & 2.5 \\
\hline & $\begin{array}{l}\text { sugars } \\
\text { free }\end{array}$ & 22.4 & 2.8 & 24.9 & 16.3 & 9.2 & 2.0 \\
\hline & aminoacids & 14.7 & 53.1 & 13.1 & 13.2 & 17.5 & 5.0 \\
\hline
\end{tabular}

union the accumulation of sucrose was also noted and its content was several times higher than in the leaves of control plants.

The reducing sugar decrease was accompanied by a several fold increase in free amino acids in the petals of wilted carnations kept in water. Use of sugar-containing holding solutions prevented free amino acid accumulation and their content in the flowers given an exogenous sugar remained at the initial level until the end of experiments.

In these experiments the differences in carnation vase-life were found to depend on the season and source of material. Table 3 shows a relationship between the reducing sugar and sucrose content in carnation petals at the time of harvest and the flower vase-life. Increase in flower longevity generally occurred as a result of the use of a preservative but the response varied due to the initial carbohydrate status of carnation petals. Flowers having high reserves of reducing sugars and sucrose had very long vase-lives which were little increased by the use of the solution of 8 -HQS plus sucrose. In contrast, carnations having about two times less sugars readilly responded to the exogenous sucrose. 


\section{Table 2}

Sucrose and reducing sugar contents in the leaves of cut carnations placed in water and in the solution of $5 \%$ sucrose plus 200 ppm 8-HQS, determined in fresh and wilted flowers

\begin{tabular}{|c|c|c|c|c|}
\hline \multirow[b]{2}{*}{ Treatments } & \multicolumn{2}{|c|}{ mg glucose/g fresh weight } & \multicolumn{2}{|c|}{ mg glucose/g dry weight } \\
\hline & $\begin{array}{l}\text { at the time } \\
\text { of harvest }\end{array}$ & $\begin{array}{l}\text { at the time } \\
\text { wilting }\end{array}$ & $\begin{array}{c}\text { at the time } \\
\text { harvest }\end{array}$ & $\begin{array}{l}\text { at the time } \\
\text { wilting }\end{array}$ \\
\hline \multicolumn{5}{|l|}{ Reducing sugars } \\
\hline $\begin{array}{l}\text { Water - control } \\
\text { Sucrose } 5 \% \text {, }\end{array}$ & 0 & 1.3 & 0 & 7.1 \\
\hline 8-HQS $200 \mathrm{ppm}$ & 0 & 4.1 & 0 & 23.1 \\
\hline \multicolumn{5}{|l|}{ Sucrose } \\
\hline $\begin{array}{l}\text { Water - control } \\
\text { Sucrose } 5 \% \text {, }\end{array}$ & 1.8 & 1.2 & 9.8 & 5.9 \\
\hline 8-HQS $200 \mathrm{ppm}$ & 1.8 & 13.1 & 9.8 & 75.0 \\
\hline
\end{tabular}

Ta ble 3

The relationship between the initial levels of reducing sugars and sucrose in carnation petals and flower vase-life in water and in the solution of $5 \%$ sucrose plus 200 ppm 8-HQS

\begin{tabular}{|c|c|c|c|c|c|}
\hline \multirow{2}{*}{$\begin{array}{c}\text { Dates of } \\
\text { experiments }\end{array}$} & \multicolumn{2}{|c|}{$\begin{array}{l}\text { Endogenous-sugars } \\
\text { in petals }\end{array}$} & \multicolumn{2}{|c|}{ Vase-life (days) } & \multirow{2}{*}{$\begin{array}{l}\% \text { increase } \\
\text { of vase-life }\end{array}$} \\
\hline & $\begin{array}{l}\text { reducing } \\
\text { sugars }\end{array}$ & sucrose & Water & 8-HQS+sucrose & \\
\hline 2 XII 1975 & 11.0 & 13.0 & 10.5 & 15.7 & 49 \\
\hline 1 VII 1976 & 10.1 & 7.2 & 9.7 & 15.1 & 56 \\
\hline 19 IV 1977 & 22.4 & 20.0 & 12.7 & 15.0 & 18 \\
\hline
\end{tabular}

It was observed in the course of experiments that the carnation flowers kept in preservatives retained their clear, unchanged color. A higher anthocyanin content was found in their petals at the time of wilting as compared to the flowers kept in water or a pure 8-HQS solution (Table 4).

Activities of acid phosphatases and RNases in carnation petals estimated on the 8th day of the experiment were lower in the flowers kept in preservatives than in control plants (Table 5). This may suggest that solution constituents affect cut flower longevity also by modifying both enzymatic systems. 
Ta ble 4

Anthocyanin levels in carnations held in water and various holding solutions determined in fresh and wilted petals and expressed as $\mathrm{E} \times 10^{3}$

\begin{tabular}{|c|c|c|c|c|c|c|}
\hline \multirow[b]{2}{*}{$\begin{array}{l}\text { Fresh } \\
\text { S.IวMoIf }\end{array}$} & \multicolumn{6}{|c|}{ Wilted flowers held in } \\
\hline & $\begin{array}{l}\text { Water } \\
\text { control }\end{array}$ & $\begin{array}{l}\text { 8-HQS } \\
200 \\
\text { ppm }\end{array}$ & $\begin{array}{c}\text { 8-HQS } 200 \\
\text { ppm, sucrose } \\
5 \%\end{array}$ & $\begin{array}{r}8 \text {-HQS } 200 \\
\text { ppm, sucrose } \\
5 \%, \text { BA } 10^{-4} \mathrm{M}\end{array}$ & $\begin{array}{c}\text { 8-HQS } 200 \\
\text { ppm, glucose } \\
5 \%, \text { CCC } 300 \text { pm }\end{array}$ & $\begin{array}{c}\mathrm{AgNO}_{3} 30 \\
\text { ppm, sucrose } \\
5 \%\end{array}$ \\
\hline 106 & 163 & 189 & 247 & 273 & 277 & 263 \\
\hline
\end{tabular}

Table 5

Activities of acid phosphatases and RNases determined in carnation petals 7 days after placing the flowers in various holding solutions

$\begin{array}{ccccc}\text { Solutions } & \text { Water } & 8 \text {-HQS } & \text { 8-HQS } & \text { 8-HQS 200 ppm } \\ \text { tested } & \text { (control) } & 200 \mathrm{ppm} & \begin{array}{c}200 \mathrm{ppm} \\ \text { sucrose } 5 \%\end{array} & \text { sucrose } 5 \% \\ & & & \text { BA } 10^{-4} \mathrm{M}\end{array}$

$\begin{array}{ccccc}\begin{array}{c}\text { Acid phosphatase } \\ \mu \mathrm{g} \mathrm{P} / \mathrm{mg} \text { protein }\end{array} & 345.8 & 328.6 & 256.2 & 249.6\end{array}$

Ribonuclease

$\begin{array}{lllll}\text { activity unit.s/mg } & 47.1 & 42.3 & 36.0 & 38.7\end{array}$

protein

\section{DISCUSSION}

A decrease in reducing sugars and sucrose is a general phenomenon accompanying the ageing of cut flowers. Placing the flowers in a sugar solution not only prevents an exhaustion of carbohydrates but also promotes their accumulation above the initial level (P a ulin, 1971; W einstein, 1957). Data presented here confirm this, however, the increase in reducing sugars varied depending on the physiological state of carnations at harvest. In the petals having low carbohydrate reserves a 2-3 fold increase was observed at wilting in the flowers kept in $8-\mathrm{HQS}+\mathrm{S}$, whereas in the petals rich in carbohydrates this increase was negligible. The presence of benzyladenine in the above solution suppressed sugar accumulation, as was also observed by Tetley and Thimann (1974) in detached oat leaves after kinetin application. A considerable increase in the sucrose level was observed in leaves of 
carnations placed in the preservative. It can be therefore assumed, especially on the basis of works of Sacalis and Durkin (1972) and $\mathrm{S}$ a calis and $\mathrm{Ch}$ in (1976) who studied translocation and distribution of labelled sucrose in cut roses, that sucrose is initially accumulated in the leaves and then is transported to petals.

The role of such high concentrations of endogenous sugars in carnation petals due to the uptake and accumulation of exogenous sucrose is still unknown. Kaltaler and Steponkus (1976) suggest that the primary function of sucrose is to maintain the structural integrity of the membranes due to its osmotic effect. Maintaining the membranes by the sugars taken from the solutions might also prevent proteolysis resulting in an increase in free amino acids as found by $\mathrm{Paulin}$ (1971) in cut rose petals. Data presented here show that the petals of carnations placed in sucrose solutions had 2-3 times less free amino acids than control flowers and had simultaneousiy considerably more endogenous sugars.

Sugar in a holding solution prevented color changes in carnation petals. Color depends on several factors including the pigment/copigment molar ratio and is therefore associated with the anthocyanin level (A s e n, 1975). It has been shown that petals of flowers placed in sugar-containing solutions had a considerably higher anthocyanin content than the carnations kept in water or pure 8-HQS solution. Presumably pigment synthesis in the petals was enhanced by sugar and this suggestion is supported by the work of $\mathbb{M}$ a ek a w a (1971) who observed an increase in the anthocyanin content in the detached carnation petals cultured on the sucrose-containing medium. More pigment was also found in cut roses held in the preservative solutions as compared to the control flowers where blueing of petals paralleled the decrease in cyanidin content (Weinstein, 1957). Thus it appears that a role of exogenous sucrose in maintaining color of cut flowers is to enhance the pigment synthesis or prevent its hydrolysis.

Lower activities of RNases and acid phosphatases were observed in the petals of flowers placed in the preservatives as compared to the control treatments. RNA degradation due to increased RNase activity is a general phenomenon associated with the senescence of plant organs (S a cher, 1973). Acid phosphatase activity which has been reported to increase during fruit ripening and plant senescence (S a c h e r, 1973) might hydrolyse ester bonds of membrane phospholipids thus affecting their permeability. According to Beute $1 \mathrm{mann}$ and Kende (1975) a decrease in phospholipids was found simultaneously with membrane degradation in wilting Ipomea flowers.

The data presented in this paper indicate that the increase in vase-iffe resulting from the use of the chemicals was due to their influence 
on certain hydrolytic enzymes. The role of sucrose should be emphasized since the solution of pure 8-HQS exerted a smaller effect than the combination of $\mathrm{S}+8-\mathrm{HQS}$.

\section{REFERENCES}

A a rts J. F. T., 1957. Over de houdbaarheid van snijbloemen. Med. Landb. Hogesch. Wageningen, No. 1974: 1-62.

A s en S., 1975. Factors affecting flower color. Acta Hort. 41: 57-68.

Beutelmann P., Kende H., 1977. Membrane lipids in senescing flower tissue of Ipomea tricolor. Plant Physiol. 58: 268-271.

Bunt A. C., 1978. Effect of season on the carnation (Dianthus caryophyllus L.). III. Flower quality. J. Hort. Sci. 53: 75-84.

Farnham D. S., Barr C., Halevy A. H., 1971. The value of using chemical solutions for conditioning and bud opening of carnations. Flor. Rev. 148: 27-28, 63-65.

Kaltaler R. E. L., Steponkus P. L., 1976. Factors affecting respiration in cut roses. J. Amer. Soc. Hort. Sci. 101: 352-354.

Lowry C. H., Rosenbrough N. J., Farr A. L., Randall R. J., 1951. Protein measurements with Folin phenol reagent. J. Biol. Chem. 193: 265-275.

Łukaszewska A., 1978. Wpływ egzogennych substancji chemicznych na trwałość kwiatów ciętych. Ph. D., SGGW-AR, Warszawa.

M a e kawa S., 1971. Studies on the coloration of carnation flowers. I. On the culture of detached petals. Sci. Rep., Fac. Agric., Kobe Univ., vol. 10: 23-26.

Nelson A., 1944. A photometric adaptation of the Somogyi method for determining glucose. J. Biol. Chem. 153: 375-380.

Paul J. L., K of ranek A. M., Kubota' J., 1977. The influence of season on cut flower conditioning responses of White Sim carnations. Acta Hort. 71: 273-277.

$\mathrm{Paulin}$ A., 1971. Influence de la composition de la solution nutritive sur le teneur en divers acides amines libres et en ammoniac des pétales de roses coupées. Ann. Technol. Agric. 20: 283-303.

Rosen H., 1957. A modified ninhydrin colorimetric analysis for aminoacides. Arch. Biochem. Biophys. 67: 10-15.

S a calis J. N., Durkin D., 1972. Movement of $\mathrm{C}^{14}$ in cut roses and carnations after uptake of $\mathrm{C}^{14}$-surose. J. Amer. Soc. Hort. Sci. 97: 481-483.

$\mathrm{S}$ a cali s J. N., C hin C. K., 1976. Metabolism of sucrose in cut roses. I. Comparison of sucrose pulse and continuous sucrose uptake. J. Amer. Soc. Hort. Sci. 101: 254-257.

Sacher J. A., 1973. Senescence and postharvest physiology. Ann. Rev. Plant Physiol. 24: 197-224.

Tetley R. M., Thimann K. V., 1974. The metabolism of oat leaves during senescence. I. Respiration, carbohydrate metabolism and action of cytokinins. Plant Physiol. 54: 294-303.

Tuve T. W., Anfinsen C. B., 1960. Preparation and properties of spinach ribonuclease. J. Biol. Chem. 235: 3437-3441.

Ty s arowski W., 1968. Biochemia Praktyczna. PZWL.

Weinstein L. H., 1957. Senescence of roses. I. Chemical changes associated with senescence of cut "Better Times" roses. Contr. Boyce Thompson Inst. 19: 33-48. 


\title{
Wpływ sacharozy w roztworze na niektóre procesy związane ze starzeniem się ciętych goździków
}

\begin{abstract}
Streszczenie
Trwałość ciętych goździków oraz ich reakcja na egzogennie zastosowaną sacharozę (łącznie z 8-HQS) byla związana z poziomem cukrów redukujących i sacharozy w płatkach kwiatów w momencie cięcia. Zawartość cukrów redukujących spadała w kwiatach przetrzymywanych w wodzie, natomiast rosła powyżej pozioinu wyjściowego w goździkach umieszczonych w roztworach cukru, przy czym wzrost ten był niewielki w kwiatach o wysokim wyjściowym poziomie cukrów, a 2-3-krotny w roślinach o niskiej zawartości cukrów w momencie cięcia. W poziomie sacharozy w płatkach goździków zachodzily mniejsze zmiany, przy czym ich kierunek zależał również od poziomu wyjściowego. Znaczna akumulacja sacharozy następowała w liściach goździków przetrzymywanych w roztworze sacharozy z 8-HQS. Egzogenne zastosowanie cukru hamowalo wzrost poziomu wolnych aminokwasów, symptomatyczny dla kwiatów przetrzymywanych w wodzie. Goździki umieszczone w roztworach zwiększających ich trwałość charakteryzowały się wyższym poziomem antocyjanów. W płatkach tych goździków stwierdzono niższą aktywność kwaśnych fosfataz i rybonukleaz w porównaniu $\mathrm{z}$ kwiatami przetrzymywanymi w wodzie.
\end{abstract}

